\title{
Transfer of formaldehyde from feed to milk during the feeding of fresh cut grass treated with formaldehyde-containing preservative
}

\author{
Matti Kreula and Aino Rauramaa \\ Biochemical Research Institute \\ Kalevankatu 56 b, 00180 Helsinki 18, Finland
}

\begin{abstract}
. 6 cows were fed for 2 weeks with fresh cut grass treated with formaldehyde-containing preservative. The formaldehyde content of the treated grass, as fed, averaged $490 \mathrm{mg} / \mathrm{kg}$ fresh weight and the consumption was $32-44 \mathrm{~kg}$ fresh material/ cow/day. The formaldehyde content of the milk rose rapidly from a pre-feed level of 0 to $0.6-2.2 \mathrm{mg} / \mathrm{kg}$, and fell to 0 immediately after the feeding period. The faeces and urine contained $150-260$ and $16-26 \mathrm{mg}$ formaldehyde/kg fresh weight respectively during the feeding period, background values being about 10 and $1 \mathrm{mg} / \mathrm{kg}$.
\end{abstract}

According to observations made so far, formaldehyde added to fresh fodder as a component of a silage preservative evaporates, polymerises and binds to fodder components relatively quickly. Ripe silage contains no more than traces of free formaldehyde (KREULA 1973, BECK and Gross 1974, KIURU et al. 1975). Any formaldehyde in silage consumed by the cow can be used in the biosynthesis of milk (KREULA 1973), and part of it may be transferred as such to milk (BECK and Gross 1974).

The purpose of the study was to measure the extent of the transfer of free formaldehyde to milk, its persistence in milk and its removal in faeces and urine when cows are given fresh cut grass treated with formaldehyde-containing preservative.

\section{Experimental}

F e e ding

The feeding was conducted with 6 Ayrshire cows at the Agricultural Research Centre, Tikkurila. The pre-test period began on August 22, 1975 when the cows were transferred from concentrates-pasture to cut-grass feeding. The feeding with cut grass treated with "Viherliuos» (Farmos Oy, 1975) was started on August 25. The grass, mainly meadow fescue, was cut with a mower chopper 
with simultaneous addition of $3-51$ Viherliuos solution per ton of grass. Fresh feed was prepared in this way every other morning. During the posttest period, September $8-11$, the cows received the same cut grass without preservative. From August 22 to September 11 the animals were housed in a cowshed. The feed was given ad libitum in the morning and evening, the unconsumed feed being weighed before the evening feeding. $150-200 \mathrm{~g}$ "Nurmituotos" mineral mixture was given per day. The mean daily feed consumption per cow during the test period was $32.2-44.2 \mathrm{~kg}$ and the mean daily milk production was $2.1-11.8 \mathrm{~kg}$.

$\mathrm{S}$ a m ples

(i) grass and feed. Each load of cut grass was sampled immediately after cutting and treating with preservative. Feed samples were taken during the weighing of the feed portions in the morning and evening.

(ii) milk. The cows were milked in the morning and evening. Morning milk from each cow was analysed separately for formaldehyde.

(iii) urine. 4 samples were taken from each cow: one, two and one during the pre-test, test and post-test periods respectively.

(iv) faeces. Samples were taken directly from the rectum. One and one sample respectively was obtained from each cow during the test and post-test periods.

Determination of formaldehyde

The formaldehyde contents of all samples were measured by a slightly modified Beck and Gross (1974) method. The chromotropic acid reaction was performed according to AOAC instructions (1975). Feed and faeces samples $(50 \mathrm{~g})$ were first homogenised with twice-distilled water $(450 \mathrm{~g})$ in a Waring Commercial Blendor.

A calibration was made by analysing beverage milk spiked with formaldehyde: 5 replicates and 8 levels of formaldehyde were used. The correlation coefficient obtained was 0.9997 . Between-cow differences were tested by means of an analysis of variance.

\section{Results and discussion}

F e e d

No formaldehyde was found in any sample which had not been treated with the preservative. The mean formaldehyde content of the freshly-treated cut grass was $940 \pm 250 \mathrm{mg} / \mathrm{kg}$ (S.D.) (7 samples, range $600-1400 \mathrm{mg} / \mathrm{kg}$ ), and that of the feed consumed by the cows $490 \pm 190 \mathrm{mg} / \mathrm{kg}$ (14 samples, range $70-700 \mathrm{mg} / \mathrm{kg}$ ). $3-5 \mathrm{l}$ "Viherliuos» solution per ton of grass is equivalent to $640-1100 \mathrm{mg} / \mathrm{kg}$ formaldehyde $/ \mathrm{kg}$.

\section{M i $1 \mathrm{k}$}

During the pre-test period no free formaldehyde was found in the milk. The mean formaldehyde content of the milk during the test period was 1.2 
$\mathrm{mg} / \mathrm{kg}$, there being no significant differences between the cows in this respect. On the first day of the post-test period the mean content had fallen to $0.7 \mathrm{mg} / \mathrm{kg}$; after this no formaldehyde could be detected (Figure 1). The formaldehyde concentrations are similar to those reported by BECK and Gross (1974), who fed preserved material with a comparable formaldehyde content.

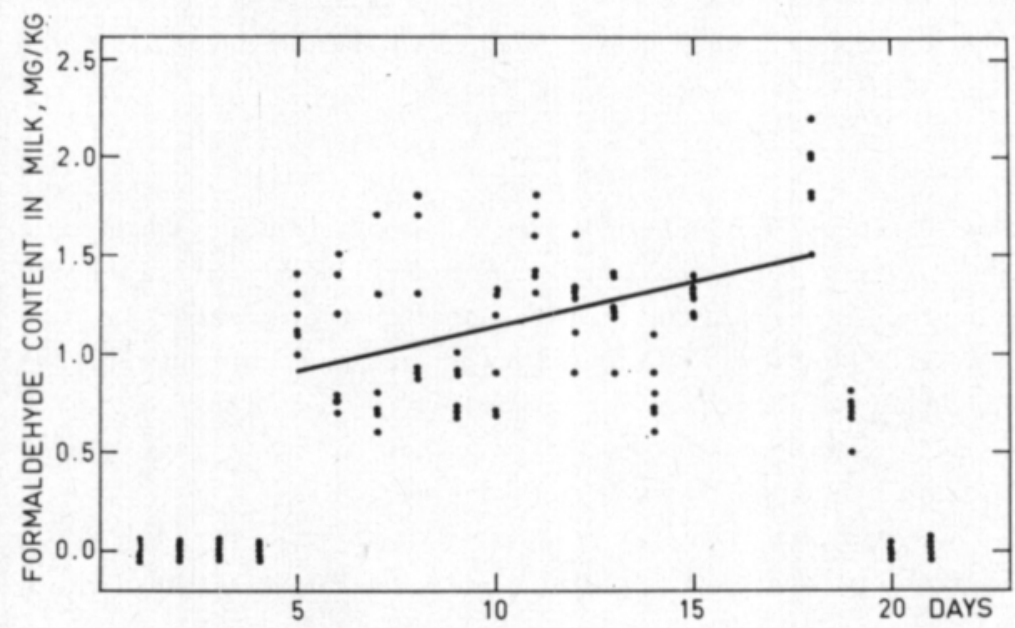

Figure 1. Formaldehyde concentration in milk during the pre-test (days 1-4), test (days $5-18$ ) and post-test (days 19-21) periods.

The effect of storage on the formaldehyde content of milk was checked by analysing sub-samples immediately, that is about one hour after milking, and after 2 and 10 days at $+5^{\circ} \mathrm{C}$. The average values found were $1.3,0.9$ and $1.3 \mathrm{mg} / \mathrm{kg}$ respectively. It appears thus that formaldehyde secreted in milk persists a considerable period of cold storage.

Table 1. Formaldehyde contents in faeces $(\mathrm{mg} / \mathrm{kg})$ during the test $(3 / 9)$ and post-test $(11 / 9)$ periods.

\begin{tabular}{ccc}
\hline Cow number & $3 / 9$ & $11 / 9$ \\
\hline 146 & 180 & 8 \\
147 & 260 & 9 \\
151 & 240 & 11 \\
154 & 195 & 10 \\
156 & 200 & 8 \\
158 & 150 & 12 \\
\hline
\end{tabular}

F a e ces and Urine

It is evident that formaldehyde is removed as such from the organism in both faeces and urine. The average level in faeces during the test period was 
$204 \pm 40 \mathrm{mg} / \mathrm{kg}$ and on the last day of the post-test period $9.7 \pm 1.6 \mathrm{mg} / \mathrm{kg}$ (Table 1). The mean formaldehyde content in the urine during the pre-test, test and post-test periods was $0.8 \pm 0.4,21.3 \pm 3.1$ and $1.4 \pm 0.2 \mathrm{mg} / \mathrm{kg}$ respectively (Table 2 ).

Table 2. Formaldehyde contents in urine $(\mathrm{mg} / \mathrm{kg})$ during the pre-test $(24 / 8)$, test $(28 / 8$ and $4 / 9)$ and post-test (11/9) periods

\begin{tabular}{ccccc}
\hline Cow number & $24 / 8$ & $28 / 8$ & $4 / 9$ & $11 / 9$ \\
\hline 146 & 0.7 & 19 & 24 & 1.3 \\
147 & 0.7 & 26 & 22 & 1.3 \\
151 & 0.8 & 23 & 16 & 1.2 \\
154 & 1.3 & 21 & 18 & 1.3 \\
156 & 0 & 19 & 21 & 1.5 \\
158 & 1.0 & 20 & 26 & 1.6 \\
\hline
\end{tabular}

We wish to express our best thanks to Dr. Vappu Kossila and the personnel of the Agricultural Research Centre who participated in the study under her direction, for the organisation of the experiment, and also for the data on feed intake and milk yield. We should also like to thank Mrs. Pirkko Lindfors, M. Agr. Sci., for practical assistance in this work.

\section{REFERENCES:}

AoAc 1975. Association of Official Agricultural Chemists, Official Methods of Analysis. 12th Ed., Washington.

BecK, TH. \& Gross, F. 1974. Zur Frage der Rückstande bei der Verwendung Formaldehydhaltiger Zusatzmittel bei der Gärfutterbereitung. Das Wirtschafteigene Futter 19: $282-289$.

KIURU, V., Moisıo, T., KreUlA, M. 1974. Säilörehujen käymistapahtumista sekä vaikutuksesta lehmän sonnan voihappobasillipitoisuuteen. Karjantuote 3:4-8.

KREULA, M. 1973. Säilörehun laatu on nyt entistä tärkeämpi. Karjatalous 4:4-6.

MS received November 6, 1975

\section{Selostus}

\section{Formaldehydin siirtyminen maitoon annettaessa formaldehydillä käsiteltyä niittoruohoa lehmille}

Mattr Kreula ja Aino Raurama

Biokemiallinen Tutkimuslaitos, Kalevankatu 56 b, 00180 Helsinki 18

Lehmille syötettiin tarharuokinnassa kahden viikon ajan formaldehydiä sisältävăllä săilöntäaineella käsiteltyä niittoruohoa. Syötetyn niittoruohon formaldehydipitoisuus oli keskimäärin $490 \mathrm{mg} / \mathrm{kg}$ tuoretta rehua. Tuoreen rehun kulutus oli lehmää kohden päivässä $32-44 \mathrm{~kg}$. Formaldehydipitoisuus maidossa nousi nopeasti esikoeajan 0-tasolta pitoisuuteen $0.6-2.2 \mathrm{mg} / \mathrm{kg}$ ja putosi 0 -tasolle välittömästi ruokintajakson päätyttyä. Ruokintajakson aikana sonta ja virtsa sisälsivät formaldehydiä $150-260$ ja $16-26 \mathrm{mg} / \mathrm{kg}$ tuorepainoa, lähtöarvot olivat 10 ja $1 \mathrm{mg} / \mathrm{kg}$. 